\title{
STRONG CONVERGENCE THEOREMS FOR BREGMAN QUASI-ASYMPTOTICALLY NONEXPANSIVE MAPPINGS AND EQUILIBRIUM PROBLEM IN REFLEXIVE BANACH SPACES
}

\author{
Y. H. ZhaO, S. S. ChANG AND J. H. ZHU
}

\begin{abstract}
The purpose of this article is to propose an iteration algorithm for Bergman quasiasymptotically nonexpansive mapping to have the strong convergence under a limit condition only in the framework of reflexive Banach spaces. As applications, we apply our results to a system of equilibrium problems. The results presented in the paper improve and extend the corresponding results of Reich and Sabach [Nonlinear Anal. 73 (2010), 122-135], Suantai et al. [Comput. Math. Appl. 64 (2012), 489-499], Nilsrakoo and Saejung [Appl. Math. Comput. 217:14 (2011), 6577-6586], Qin et al. [Applied Math Letters, 22 (2009), 1051-1055], Wang et al. [J. Comput. Appl. Math., 235 (2011), 2364-2371], Su et al. [Nonlinear Anal. 73 (2010), 390-3906], Nartinez-Yanes et al. [Nonlinear Anal., 64 (2006), 2400-2411] and others.
\end{abstract}

Mathematics subject classification (2010): 47J05, 47H09, 49J25.

Keywords and phrases: Bergman quasi-asymptotically nonexpansive mapping, Bergman strongly nonexpansive mapping, Legendre function, totally convex function, Bergman quasi-nonexpansive mapping, Bergman projection.

\section{REFERENCES}

[1] H. H. BauschKe, J. M. Borwein, P. L. Combettes, Essential smoothness, essential strict convexity, and Legendre functions in Banach spaces, Commun. Contemp. Math., 3 (2001), 615-647.

[2] F. E. BROWDER, Fixed point theorems for noncompact mappings in Hilbert space, Proc. Natl. Acad. Sci. USA, 53 (1965) 1272-1276.

[3] D. BUTNARIU, Y. CENSOR, S. REICH, Iterative averaging of entropic projections for solving stochastic convex feasibility problems, Comput. Optim. Appl., 8 (1997), 21-39.

[4] D. Butnariu, A. N. Iusem, Totally Convex Functions for Fixed Points Computation and Infinite Dimensional Optimization, Kluwer Academic Publishers, Dordrecht, 2000.

[5] D. BUTNARIU, E. RESMERITA, Bregman distances, totally convex functions and a method for solving operator equations in Banach spaces, Abstr. Appl. Anal., 2006 (2006) 1-39. Art. ID 84919.

[6] Y. CENSOR, A. Lent, An iterative row-action method for interval convex programming, J. Optim. Theory Appl., 34 (1981), 321-353.

[7] S. S. Chang, C. K. Chan, H. W. Joseph Lee, Modified Block iterative algorithm for quasi- $\phi$ asymptotically nonexpansive mappings and equilibrium problem in Banach spaces, Applied Math. Comput., 10.1016/j.amc.2011.02.060.

[8] S. S. Chang, H. W. JosePh LeE, Chi Kin Chan, A new hybrid method for solving a generalized equilibrium problem solving a variational inequality problem and obtaining common fixed points in Banach spaces with applications, Nonlinear Anal. TMA, 73 (2010), 2260-2270.

[9] B. Halpern, Fixed points of nonexpanding maps, Bull. Amer. Math. Soc., 73 (1967) 957-961.

[10] J. KANG, Y. SU, X. ZHANG, Hybrid algorithm for fixed points of weak relatively nonexpansive mappings and applications, Nonlinear Anal. HS, (2010), doi:10.1016/j.nahs.2010.05.002.

[11] C. MartineZ-Yanes, H. K. XU, Strong convergence of the CQ method for fixed point iteration processes, Nonlinear Anal., 64 (2006) 2400-2411. 
[12] W. Nilsrakoo, S. Saejung, Strong convergence theorems by Halpern-Mann iterations for relatively nonexpansive mappings in Banach spaces, Appl. Math. Comput., 217:14 (2011), 6577-6586.

[13] X. L. QIN, Y. J. Cho, S. M. KANG, H. Y. Zhou, Convergence of a modified Halpern-type iterative algorithm for quasi- $\phi$-nonexpansive mappings, Applied math. Letters 22 (2009), 1051-1055.

[14] X. QIN, Y. SU, Strong convergence theorems for relatively nonexpansive mappings in a Banach space, Nonlinear Anal., 67 (2007) 1958-1965.

[15] S. REICH, S. SABACH, Two strong convergence theorems for Bregman strongly nonexpansive operators in reflexive Banach spaces, Nonlinear Analysis, 73 (2010), 122-135.

[16] S. REICH, S. SABACH, Two strong convergence theorems for a proximal method in reflexive Banach spaces, Numerical Functional Analysis and Optimization, 31 (1) (2010), 22-44.

[17] S. SABACH, Products of finitely many resolvents of maximal monotone mappings in reflexive Banach spaces, SIAM J. Optim., 21:4 (2011), 1289-1308.

[18] Y. F. SU, H. K. XU, X. ZHANG, Strong convergence theorems for two countable families of weak relatively nonexpansive mappings and applications, Nonlinear Anal., 73 (2010), 3890-3906.

[19] S. SuAntAI, Y. J. CHO, P. CHOlAMJIAK, Halpern's iteration for Bregman strongly nonexpansive mappings in reflexive Banach spaces, Comput. Math. Appl. 64 (2012), 489-499.

[20] Z. M. WANG, Y. F. SU, D. X. WANG, Y. C. Dong, A modified Halpern-type iteration algorithm for a family of hemi-relative nonexpansive mappings and systems of equilibrium problems in Banach spaces, J. Comput. Applied Math., 235 (2011), 2364-2371. 